\title{
KOLONOSKOPIA - PROBLEMY PACJENTÓW PRZYGOTOWUJĄCYCH SIĘ DO BADANIA
}

\section{COLONOSCOPY - PROBLEMS OF PATIENTS PREPARING FOR MEDICAL EXAMINATION}

\author{
Elżbieta Antos', Jolanta Maliszewska², Małgorzata Wojciechowska' \\ 'Wydział Rehabilitacji, Zakład Pielęgniarstwa Klinicznego \\ Akademia Wychowania Fizycznego Józefa Piłsudskiego w Warszawie \\ ${ }^{2}$ Instytut Pielęgniarstwa \\ Collegium Masoviense, Wyższa Szkoła Nauk o Zdrowiu w Żyrardowie \\ DOl: https://doi.org/10.20883/ppnoz.2019.25
}

\section{STRESZCZENIE}

Wstęp. Kolonoskopia jest badaniem endoskopowym, pozwalającym dokonać oceny makroskopowej błony śluzowej całego jelita grubego. Badania endoskopowe są badaniami inwazyjnymi, obarczonymi wieloma powikłaniami, a niepożądane sytuacje wynikają często z nieprawidłowego przygotowania pacjenta do badania.

Cel pracy. Poznanie problemów pacjentów przygotowujących się do badania kolonoskopowego.

Materiał i metody. Badanie przeprowadzono w Centralnym Szpitalu Klinicznym Ministerstwa Spraw Wewnętrznych w Warszawie przy ul. Wołoskiej 137, w Pracowni Endoskopii i w Klinice Chorób Wewnętrznych i Gastroenterologii z Pododdziałem Leczenia Nieswoistych Chorób Zapalnych Jelit, wśród 100 pacjentów, którzy zgłosili się do Programu Profilaktyki Raka Jelita Grubego i byli hospitalizowani. Posłużono się metodą sondażu diagnostycznego, jako technikę badawczą zastosowano ankietowanie, narzędziem badawczym był autorski kwestionariusz ankiety.

Wyniki. Pacjenci przygotowujący się do badania kolonoskopowego ocenili instrukcję przygotowania do badania na wysokim poziomie, natomiast negatywnie ocenili smak i ilość preparatu przeczyszzzającego. Dla większości pacjentów etap przygotowania był trudny. Większości respondentów objawy występujące podczas przyjmowania preparatu utrudniały wypicie go.

Wnioski. Kolonoskopia generuje wysoki poziom lęku u pacjenta, którego źródłem jest przede wszystkim obawa o wynik badania oraz świadomość moż-

liwych powikłań. Należy poszukiwać preparatu, który pozwoliłby w optymalny, przyjazny dla pacjenta sposób przygotować jelita do badania oraz zwiększyć udział badań z sedacją.

Słowa kluczowe: endoskopia, opieka pielęgniarska, rak jelita grubego.

ABSTRACT

Introduction. Colonoscopy is an endoscopic examination which makes it possible to macroscopically evaluate mucous membranes of the whole large intestine. Endoscopy is an invasive examination with a risk of complications; undesirable situations often result from inadequate preparation of the patient to the examination.

Aim. Getting to know the problems of patients preparing for colonoscopy.

Material and methods. The research was carried out in Central Clinical Hospital of the Ministry of Interior in Warsaw at Wołoska 137, in the Endoscopy Laboratory and in the Internal Diseases and Gastroenterology Department with a Sub-department for Treatment of Inflammatory Bowel Diseases, among 100 patients who volunteered to Program of Colorectal Cancer Prophylaxis and were hospitalised. To collect research material, a diagnostic poll method was applied with the use of a survey; the research tool applied was an original survey questionnaire.

Results. The patients who were preparing for a colonoscopy examination assessed the instruction of preparation for the examination high, while they expressed negative opinions about the taste and amount of laxative liquid. For the majority of patients the preparatory stage was hard. Most respondents had problems drinking the liquid due to the symptoms experienced during the process.

Conclusions. Colonoscopy generates high level of anxiety in patients, the source of which is mainly fear about the examination results and possible complications. It is important to look for the medication that will make it possible to prepare a patient for the examination in an optimal and friendly way and increase the number of examinations of sedated patients.

Keywords: endoscopy, nursing care, colorectal cancer.

\section{Wstęp}

Kolonoskopia jest badaniem endoskopowym pozwalającym dokonać oceny makroskopowej błony śluzowej całego jelita grubego [1]. Polega ona na wprowadzeniu do światła jelita grubego giętkiego endoskopu zwanego kolonoskopem, zbudowanego z włókna szklanego, o długości
130-200 cm i grubości zbliżonej do grubości palca dorosłej osoby [2, 3]. Obecnie używane aparaty zaopatrzone są w mikrokamery, pozwalające na oglądanie i rejestrację wnętrza jelita na monitorze w naturalnych barwach.

Kolonoskopię wykonuje się w celach diagnostycznych (ustalenie rozpoznania, pobranie materiału do badania 
histopatologicznego), terapeutycznych (lecznicze wykonanie polipektomii) oraz od 2000 roku w Polsce jako badanie profilaktyczne, skriningowe (w kierunku wczesnego wykrywania raka jelita grubego wykrycie zmian w okresie bezobjawowym). Usuwanie wszystkich polipów w trakcie badania kolonoskopowego wpływa na zmniejszenie ryzyka zachorowania na raka jelita grubego o 76-90\% [4].

Dla wielu Polaków badania proktologiczne, między innymi kolonoskopia, jest wciąż pewnym novum i często tematem wstydliwym. Specyficzny charakter badania oraz wymagające przygotowanie nie zachęcają do wykonywania badania kolonoskopowego $w$ ramach programu profilaktycznego [5].

Rak jelita grubego jest nowotworem podstępnym, rozwija się przez wiele lat, nie dając żadnych objawów. W większości przypadków powstaje na podłożu polipów - łagodnych gruczolaków, które tworzą się na wewnętrznych ścianach jelit. Przemiana polipa w nowotwór trwa około 7-12 lat. Według danych z 2010 roku rak jelita grubego jest trzecią przyczyną zgonów wśród mężczyzn - po raku płuca i prostaty, a drugą wśród kobiet - po raku piersi [4]. Rak jelita grubego pod względem umieralności zajmuje w Polsce drugie miejsce u obydwu płci. Zachorowalność na nowotwór jelita grubego stanowi u mężczyzn około 12\%, a u kobiet $10 \%$ spośród wszystkich chorób nowotworowych. Prawie czterokrotny u mężczyzn i trzykrotny u kobiet wzrost liczby zachorowań odnotowano od 1980 roku. Wydłużanie się długości życia zarówno w Polsce, jakiw krajach europejskich oraz wzrostliczby osób po 65 roku życia przyczynia się do znacznego wzrostu zachorowań na nowotwory, w tym również na nowotwory jelita grubego $[7,8]$

W Polsce od października 2000 roku rozpoczęto realizację programu badań skriningowych w kierunku wykrywania raka jelita grubego, a od 2005 roku na mocy ustawy z dnia 1 lipca 2005 roku „O ustanowieniu programu wieloletniego Narodowy Program Zwalczania Chorób Nowotworowych" rozpoczęto realizację Narodowego Programu Zwalczania Chorób Nowotworowych, w którym jednym z zadań był Program Badań Przesiewowych dla wczesnego wykrywania raka jelita grubego. Od 2012 roku program roku realizowany jest $w$ dwóch systemach: przesiewu oportunistycznego (osoby same zgłaszają się do wybranego ośrodka na badanie lub kierowane są przez lekarza rodzinnego) i przesiewu aktywnego (osoby do badania otrzymują imienne zaproszenie na badanie ze wskazaniem ośrodka).

Uważa się, że kolonoskopia jest najskuteczniejszą i najbardziej kosztoefektywną metodą skriningu. Stosowanie sedacji w trakcie procedur endoskopowych zapewnia pa- cjentowi komfort i bezpieczeństwo, natomiast lekarzowi ułatwia wykonanie badania oraz poprawia jego efektywność [9].

Na przygotowanie pacjenta do badania kolonoskopowego powinno się sumować przygotowanie psychiczne i fizyczne. Obydwa elementy stanowią nieodzowną całość w pełnym przygotowaniu pacjenta do tej procedury medycznej. Fizyczne przygotowanie pacjenta składa się z wielu uwarunkowanych od siebie elementów, jednak końcowy efekt badania zależny jest w głównej mierze od przygotowania przewodu pokarmowego [10]. W przypadku badania kolonoskopowego dobre przygotowanie psychiczne, $z$ uwagi na ingerencję $w$ intymność pacjentów, jest nieodzownym elementem, którego nie powinno zabraknąć. Pacjenci poddawani kolonoskopii często przeżywają silne emocje, przez które niejednokrotnie rezygnują z podjęcia leczenia. Komunikacja, która stanowi część przygotowania psychicznego, wiedzie prym w procesie diagnostycznoleczniczym, przekładając się na każdy aspekt hospitalizacji. Natomiast dobry stan psychiczny pacjenta warunkuje szybsze uzyskanie oczekiwanych wyników terapii.

Działania edukacyjne pielęgniarki i opiekuńczo-terapeutyczne realizowane są przed badaniem, w trakcie i po badaniu. Jednym z ważniejszych działań jest edukacja pacjenta w zakresie diety oraz przygotowania i wypicia preparatu przygotowującego przewód pokarmowy. Pacjenci wykonujący badanie w warunkach ambulatoryjnych powinni mieć udzielone szczegółowe instrukcje dotyczące przygotowania do badania. Pielęgniarka powinna również udzielić informacji na temat objawów, jakie mogą wystąpić w trakcie przyjmowania preparatu przeczyszczającego. Rolą pielęgniarki jest stworzenie odpowiedniej atmosfery przed i w czasie badania, okazanie pacjentowi zainteresowania, życzliwości, zapewnienie intymności i poszanowanie godności osobistej [11, 12].

\section{Cel pracy}

Celem badania było poznanie problemów pacjentów przygotowujących się do badania kolonoskopowego.

\section{Materiał i metoda}

Badanie przeprowadzono w Centralnym Szpitalu Klinicznym Ministerstwa Spraw Wewnętrznych w Warszawie przy ul. Wołoskiej 137, w Pracowni Endoskopii oraz w Klinice Chorób Wewnętrznych i Gastroenterologii z Pododdziałem Leczenia Nieswoistych Chorób Zapalnych Jelit.

Badanie przeprowadzono wśród 100 pacjentów poddanych kolonoskopii, którzy zgłosili się do Programu Profilaktyki Raka Jelita Grubego i byli hospitalizowani, w okresie od września 2014 roku do stycznia 2015 roku. Udział an- 
kietowanych w badaniu był dobrowolny i anonimowy, a dobór respondentów losowy.

Posłużono się metodą sondażu diagnostycznego, jako technikę badawczą zastosowano ankietowanie, narzędziem badawczym był autorski kwestionariusz ankiety, który składał się z 26 pytań.

W badaniu wzięło udział $57 \%$ kobiet i $43 \%$ mężczyzn. W analizowanej grupie $61 \%$ badanych stanowiły osoby powyżej 50 roku życia, w tym powyżej 65 lat - 12\%. W grupie osób poniżej 50 roku życia $18 \%$ stanowili respondenci w wieku 20-39 lat, a 21\% w wieku 40-49 lat.

W analizowanej grupie $52 \%$ badanych miało wykształcenie średnie, a 43\% ukończyło studia wyższe. W pozostałych przypadkach uzyskane przez respondentów wykształcenie było następujące: szkoła podstawowa $-1 \%$ oraz szkoła zawodowa $-4 \%$. Zestawienie danych wskazuje, że w badaniu wzięło więcej mieszkańców miast (81\%) niż wsi (19\%). W analizowanej grupie $66 \%$ badanych funkcjonowało w związkach małżeńskich lub partnerskich. Osoby mieszkające samotnie stanowiły $16 \%$ grupy, a mieszkające z dziećmi - 18\%.

Uzyskane wyniki zostały poddane analizie statystycznej z zastosowaniem testu t-Studenta. Wnioskowanie statystyczne przeprowadzono przy standaryzowanym poziomie istotności $p<0,05$. Opis i interpretacja zależności zmiennych była określona na podstawie współczynnika korelacji Pearsona. Do wykonania analizy statystycznej użyto programu Statistica 7.0.

\section{Wyniki}

W badanej grupie udział pacjentów skierowanych na kolonoskopię przez lekarza wynosił $48 \%$, badanie w ramach programu profilaktycznego raka jelita grubego wykonywało $52 \%$ respondentów.

Dla 78\% ankietowanych analizowana kolonoskopia była pierwszą $w$ ich życiu, dla $22 \%$ respondentów była kolejnym tego typu badaniem.

W badanej grupie 55\% pacjentów relacjonowało, że badanie kolonoskopowe zostało przeprowadzone bez znieczulenia, 33\% ze znieczuleniem, 5\% po podaniu środków przeciwbólowych, 7\% pacjentów nie miało wiedzy na temat zastosowanej farmakoterapii. Mężczyźni istotnie częściej niż kobiety przygotowywali się do badania ze świadomością braku znieczulenia. Brakiem wiedzy w tym zakresie znacząco częściej wykazali się mężczyźni niż kobiety. Analiza danych wykazała, że respondenci w wieku 20-39 lat istotnie częściej oczekiwali znieczulenia podczas kolonoskopii niż badani w pozostałych grupach wiekowych (Tabela 1).

Zdaniem ankietowanych otrzymana instrukcja w zakresie przygotowania się do badania był zrozumiała - $78 \%$, i czytelna - 29\%. Opinię przeciwną wystawiło 11\% respondentów. Zestawienie danych badawczych wskazuje, że mężczyźni istotnie częściej niż kobiety uważali otrzymaną instrukcję za niezrozumiałą (Tabela 2).

Tabela 1. Świadomość wykonania kolonoskopii w znieczuleniu z uwzględnieniem wieku respondenta

\begin{tabular}{|c|c|c|c|c|c|c|c|c|c|c|}
\hline \multirow{2}{*}{ Odpowiedź } & \multicolumn{2}{|c|}{ 20-39 lat } & \multicolumn{2}{|c|}{ 40-49 lat } & \multicolumn{2}{|c|}{$50-65$ lat } & \multicolumn{2}{|c|}{$\begin{array}{c}\text { Powyżej } \\
65 \text { lat }\end{array}$} & \multirow{2}{*}{$\begin{array}{c}\text { Wspoicsynnik } \\
\text { koreiacji } \\
\text { Poarsona } \\
{[\mathrm{r}]}\end{array}$} & \multirow{2}{*}{ 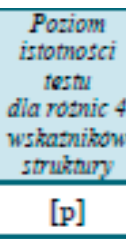 } \\
\hline & [n] & {$[\%]$} & [n] & {$[\%]$} & [n] & {$[\%]$} & {$[\mathrm{n}]$} & {$[\%]$} & & \\
\hline Bez znieczulenia & 5 & 27,8 & 14 & 66,7 & 32 & 65,3 & 4 & 33,3 & 0,104 & $0,304^{*}$ \\
\hline Ze znieczuleniem & 11 & 61,1 & 4 & 19,0 & 16 & 32,7 & 2 & 16,7 & $-0,211$ & 0,035 \\
\hline Leki przeciwbólowe & 2 & 11,1 & 2 & 9,5 & 1 & 2,0 & 0 & 0,0 & $-0,187$ & $0,063^{*}$ \\
\hline Brak wiedzy & 0 & 0,0 & 1 & 4,8 & 0 & 0,0 & 6 & 50,0 & 0,347 & $<0,001$ \\
\hline RAZEM & 18 & 100 & 21 & 100 & 49 & 100 & 12 & 100 & & \\
\hline
\end{tabular}

${ }^{*}$ wynik testu nieistotny statystycznie $(p \geq 0,05)$

Źródlo: badania wlasne 
Tabela 2. Ocena jakości otrzymanej instrukcji przygotowania się do badania z uwzględnieniem płci respondenta

\begin{tabular}{|c|c|c|c|c|c|c|}
\hline \multirow[t]{2}{*}{ Odpowiedź } & \multicolumn{2}{|c|}{ Kobiety } & \multicolumn{2}{|c|}{ Mẹżczyźni } & \multirow{2}{*}{$\begin{array}{c}\begin{array}{c}\text { Wspoicsymik }_{\text {korelacji }} \\
\text { Pearsona }\end{array} \\
{[\mathrm{r}]}\end{array}$} & \multirow{2}{*}{$\begin{array}{c}\text { Posiom } \\
\text { istotnosci testu } \\
\text { dila rosnic 2 } \\
\text { wskntnikow } \\
\text { struknuy } \\
\text { [p] }\end{array}$} \\
\hline & {$[\mathrm{n}]$} & {$[\%]$} & {$[\mathrm{n}]$} & {$[\%]$} & & \\
\hline Zrozumiala & 48 & 84,2 & 30 & 69,8 & $-0,173$ & $0,086^{*}$ \\
\hline Czytelna & 14 & 24,6 & 15 & 34,9 & 0,113 & $0,265^{*}$ \\
\hline Niezrozumiala & 0 & 0,0 & 5 & 11,6 & 0,264 & 0,008 \\
\hline Malo czytelna & 1 & 1,8 & 3 & 7,0 & 0,132 & $0,191 *$ \\
\hline Nie otrzymalam/otrzymalem instrukcji & 0 & 0,0 & 0 & 0,0 & - & - \\
\hline RAZEM & 57 & 100 & 43 & 100 & & \\
\hline
\end{tabular}

${ }^{*}$ wynik testu nieistotny statystycznie $(p \geq 0,05)$

Źródlo: badania wlasne

Respondenci w wieku powyżej 65 roku życia istotnie częściej uważali otrzymaną instrukcję za niezrozumiałą. Otrzymano, że osoby z niższym wykształceniem istotnie częściej niż pozostałe miały problemy ze zrozumieniem otrzymanej instrukcji.

Większość respondentów (84\%) otrzymała wyjaśnienie od personelu medycznego w zakresie przygotowania się do badania. Odpowiedzi przeczącej udzieliło 3\% ankietowanych, a 13\% uznało, że nie było to konieczne. Większość respondentów oceniła pozytywnie jakość otrzymanych wyjaśnień: $56 \%$ uznało je za zrozumiałe, $36 \%$ za wystarczające. Nie stwierdzono istotnych korelacji pomiędzy udzieloną odpowiedzią a płcią, wiekiem czy poziomem wykształcenia respondenta $(p \geq 0,05)$.

Zbadano opinię respondentów w zakresie, czy choroby wspótistniejące utrudniały im przygotowanie się do badania. Odpowiedzi pozytywnej udzieliło $29 \%$ ankie- towanych, negatywnej $47 \%$, natomiast $17 \%$ stwierdziło, że nie cierpi na żadne dolegliwości, w związku z tym nie ma punktu odniesienia tej kwestii. Zestawienie danych wskazuje, że kobiety częściej niż mężczyźni były zdania, że choroby wspótistniejące nie stanowią przeszkody w wykonaniu badania. Wśród mężczyzn co czwarty określił, że nie cierpi na inne dolegliwości, a tym samym nie może odnieść się do tego problemu. Nie stwierdzono istotności korelacji. Analiza danych wykazała, że respondenci w wieku powyżej 65 roku życia istotnie częściej uważali, że choroby wspótistniejące utrudniają wykonanie kolonoskopii. Opinia ta jest najbardziej miarodajna, gdyż w tej grupie wiekowej obciążenie chorobowe były najwyższe. Otrzymano, że osoby z wyższym wykształceniem istotnie częściej niż pozostałe nie uważały, aby schorzenia dodatkowe były znaczącą przeszkodą w wykonaniu kolonoskopii (Tabela 3).

Tabela 3. Choroby współistniejące jako przeszkoda w kolonoskopii z uwzględnieniem wieku respondenta

\begin{tabular}{|c|c|c|c|c|c|c|c|c|c|c|}
\hline \multirow[t]{2}{*}{ Odpowiedź } & \multicolumn{2}{|c|}{ 20-39 lat } & \multicolumn{2}{|c|}{ 40-49 lat } & \multicolumn{2}{|c|}{ 50-65 lat } & \multicolumn{2}{|c|}{$\begin{array}{c}\text { Powyżej } \\
65 \text { lat }\end{array}$} & \multirow{2}{*}{$\begin{array}{c}\text { Wspoiczynnik } \\
\text { korelacji } \\
\text { Poarsona } \\
\\
{[\mathrm{r}]}\end{array}$} & \multirow{2}{*}{$\begin{array}{c}\text { Poziom } \\
\text { istotnosci } \\
\text { testu } \\
\text { dia rosnic } 4 \\
\text { wskasnikow } \\
\text { struksury } \\
\text { [p] }\end{array}$} \\
\hline & [n] & {$[\%]$} & [n] & {$[\%]$} & [n] & [\%] & [n] & {$[\%]$} & & \\
\hline Zdecydowanie tak & 0 & 0,0 & 0 & 0,0 & 0 & 0,0 & 2 & 16,7 & \multirow{8}{*}{$-0,327$} & \multirow{8}{*}{$<0,001$} \\
\hline Raczej tak & 2 & 11,1 & 1 & 4,8 & 6 & 12,2 & 5 & 41,6 & & \\
\hline Tak & 0 & 0,0 & 5 & 23,8 & 6 & 12,2 & 2 & 16,7 & & \\
\hline Trudno powiedzieć & 2 & 11,1 & 0 & 0,0 & 5 & 10,2 & 0 & 0,0 & & \\
\hline Nie & 7 & 38,9 & 3 & 14,3 & 21 & 42,9 & 3 & 25,0 & & \\
\hline Raczej nie & 4 & 22,2 & 2 & 9,5 & 3 & 6,1 & 0 & 0,0 & & \\
\hline Zdecydowanie nie & 1 & 5,6 & 1 & 4,8 & 2 & 4,1 & 0 & 0,0 & & \\
\hline $\begin{array}{l}\text { Nie cierpię na } \\
\text { inne dolegliwości }\end{array}$ & 2 & 11,1 & 9 & 42,8 & 6 & 12,3 & 0 & 0,0 & & \\
\hline RAZEM & 18 & 100 & 21 & 100 & 49 & 100 & 12 & 100 & {$[\mathrm{~N}=$} & \\
\hline
\end{tabular}

${ }^{*}$ wynik testu nieistotny statystycznie $(p \geq 0,05)$

\section{Zródlo: badania wlasne}


Zbadano opinię respondentów w zakresie, czy przyjmowane leki utrudniały przygotowanie się do badania. Odpowiedzi pozytywnej udzieliło $30 \%$ ankietowanych, a negatywnej $70 \%$. Nie stwierdzono istotnych korelacji $(p \geq 0,05)$.

Wykonanie badania kolonoskopowego wymaga od pacjenta rozebrania się przed personelem medycznym. Sytuacja ta wywoływała poczucie wstydu u 55\% respondentów, problem ten nie dotyczył 33\% ankietowanych, odpowiedzi "trudno powiedzieć" udzieliło 12\% respondentów. Stwierdzono, iz poczucie wstydu istotnie częściej towarzyszyło kobietom niż mężczyznom. Wraz z wiekiem ankietowanych poczucie wstydu obniżało się. Nie stwierdzono istotnych korelacji $(p \geq 0,05)$.

Zdaniem większości respondentów (78\%) wstyd nie utrudniał im przygotowania się do badania. Opinię przeciwną wyraziło $6 \%$ badanych, odpowiedzi „trudno powiedzieć" udzieliło 16\% respondentów. Stwierdzono, iż wstyd istotnie częściej utrudniał przygotowanie się do badań kobietom niż mężczyznom. Problem z przygotowaniami do badań powodowane poczuciem wstydu najczęściej odczuwały osoby po 65 roku życia. Nie stwierdzono istotnych korelacji $(p \geq 0,05)$.

Zestawienie danych badawczych wskazuje, że lęk przed badaniem odczuwało 89\% respondentów. Swój lęk respondenci tłumaczyli oczekiwaniem na wynik badania (79\%). Jako inne przyczyny wskazali również obawę przed powikłaniami (42\%), brak znieczulenia (33\%) oraz zbyt małą wiedzę o przebiegu badania (15\%). Zestawienie danych wskazuje, że lęk u mężczyzn częściej wywoływała obawa o wynik badania, u kobiet - możliwość wystąpienia powikłań. Nie stwierdzono istotnych korelacji.

Najczęściej lęk przed wynikiem badania odczuwały osoby najmłodsze 20-39 lat. W grupie wiekowej 40-49 lat, częściej niż w innych grupach, lęk generował brak znieczulenia przy badaniu. Pacjenci w wieku 50-65 lat najczęściej odczuwali niedosyt posiadanej wiedzy. Respondenci w wieku powyżej 65 lat częściej niż pozostali obawiali się możliwych powikłań. Stwierdzono, że w grupie osób z wyższym wykształceniem lęk przed badaniem istotnie częściej generowany był przez obawę przed jego wynikiem. Natomiast respondenci z niższym wykształceniem istotnie częściej obawiali się możliwych powikłań oraz swój niepokój tłumaczyli niskim poziomem posiadanej wiedzy (Tabela 4).

Zdaniem 8\% ankietowanych smak podawanego preparatu do przygotowania przed badaniem był akceptowalny, a dla $19 \%$ obojętny. Negatywnie smak płynu odbierało 64\% respondentów, a 48\% uważało, że jest go za dużo.

W trakcie przyjmowania preparatu respondenci swoje samopoczucie opisali głównie jako "miałam/miałem nudności" (44\%) oraz „bolał mnie brzuch" (33\%). Co czwarty pacjent odczuwał głód lub osłabienie. Odpowiedź "robiło mi się słabo" wskazało 7\% badanych. Dobre samopoczucie $\mathrm{w}$ trakcie przyjmowania miało $25 \%$ ankietowanych pacjentów. Zdaniem 66\% respondentów występujące objawy utrudniały im wypicie preparatu. Opinię przeciwną wyraziło $26 \%$ badanych, a $8 \%$ nie spożyło zalecanej dawki płynu.

Niemożność spożywania określonych produktów przed badaniem była utrudnieniem dla $56 \%$ respondentów, w tym u 26\% objawiało się to zwiększaniem się uczucia głodu, a u 18\% nasilała się myśl o jedzeniu.

W trakcie przygotowywania do badania respondenci najczęściej odczuwali ból i pieczenie odbytu - 59\% badanych. Żadnych dolegliwości nie zgłaszało 17\%, 12\% odczuwało dreszcze, krwawienie z odbytu obserwowało $8 \%$, nudności i wymioty zgłaszało $4 \%$ badanych. Dolegliwości podczas przygotowania do badania najrzadziej występowały u osób w wieku 20-39 lat, jednak skarżyło się na nie 100\% badanych powyżej 65 roku życia. Odczuwane dolegliwości utrudniały przygotowanie się do badania 59\% respondentów, dla $41 \%$ badanych nie były przeszkodą w przygotowaniu się do badania.

Zdaniem 67\% przygotowanie do kolonoskopii jest trudne, opinię przeciwną wyraziło $28 \%$ badanych, „trudno powiedzieć" odpowiedziało 5\% respondentów.

Tabela 4. Przyczyny lęku przed kolonoskopią z uwzględnieniem wykształcenia respondenta

\begin{tabular}{|c|c|c|c|c|c|c|}
\hline \multirow[t]{2}{*}{ Odpowiedź } & \multicolumn{2}{|c|}{$\begin{array}{l}\text { Wylssztalcenie } \\
\text { niższe }\end{array}$} & \multicolumn{2}{|c|}{$\begin{array}{c}\text { Wyksztalcenie } \\
\text { wyższe }\end{array}$} & \multirow{2}{*}{$\begin{array}{c}\begin{array}{c}\text { Wspolicsunnik } \\
\text { korviacji } \\
\text { Poarsona }\end{array} \\
{[\mathrm{r}]}\end{array}$} & \multirow{2}{*}{ 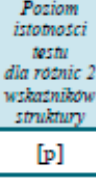 } \\
\hline & [n] & {$[\%]$} & [n] & [\%] & & \\
\hline $\begin{array}{c}\text { zbyt mala wiedza na temat } \\
\text { przebiegu badania }\end{array}$ & 12 & 21,1 & 3 & 7,0 & $-0,205$ & 0,049 \\
\hline możliwość wystapienia powiklań & 25 & 43,9 & 17 & 39,5 & $-0,043$ & $0,668^{*}$ \\
\hline wynik badania & 41 & 71,9 & 38 & 88,4 & 0,209 & 0,046 \\
\hline brak znieczulenia podczas badania & 26 & 45,6 & 7 & 16,3 & $-0,309$ & 0,002 \\
\hline RAZEM & 57 & 100 & 43 & 100 & \multicolumn{2}{|c|}{$[N=100]$} \\
\hline
\end{tabular}




\section{Dyskusja}

Kolonoskopia należy do podstawowych procedur diagnostycznych w chorobach dolnego odcinka przewodu pokarmowego, jest badaniem dokładnym, wykrywalność zmian sięga około 75\% [12].

Konstytucja RP każdemu zapewnia nietykalność i wolność osobistą [13]. Na tej podstawie każdy pacjent ma prawo do wyrażenia zgody lub odmowy proponowanych mu sposobów postępowania medycznego. Dotyczy to zarówno leczenia, jak i diagnostyki, profilaktyki, rehabilitacji i innych świadczeń z zakresu ochrony zdrowia. Według obecnie obowiązującego kodeksu karnego przeprowadzenie zabiegu leczniczego bez zgody pacjenta jest przestępstwem [14].

Kolonoskopia zaliczana jest do zabiegów medycznych określanych jako ryzykowne, w tej sytuacji prawo polskie wymaga pobrania zgody $w$ formie pisemnej. Decyzja o zgodzie na zabieg musi być świadoma, dlatego w procesie pozyskiwania zgody na udzielenie określonych świadczeń medycznych lub ich odmowy, pacjent musi uzyskać pełną informację i wiedzę o planowanym zabiegu. Informacja musi być przystępna, czyli przedstawiona $w$ formie uwzględniającej poziom intelektualny odbiorcy i być dla niego zrozumiała $[13,15]$. Pacjent wyrażając zgodę na zabieg operacyjny akceptuje ryzyko zabiegu i godzi się z możliwością potencjalnych powikłań [15]. Brak lub niedostateczny poziom wiedzy pacjenta, nieprawdziwe bądź wyolbrzymione informacje mogą generować niepokój, lęk oraz inne negatywne emocje, które niewątpliwie niekorzystanie wpływają na przebieg badania i związane z tym dolegliwości bólowe [12].

W badaniach własnych, zdaniem ankietowanych, otrzymana instrukcja w zakresie przygotowania się do badania był zrozumiała - 78\%, i czytelna - 29\%. Opinię przeciwną zgłosiło $11 \%$ respondentów. Analiza danych wykazała, że mężczyźni oraz respondenci w wieku powyżej 65 roku życia istotnie częściej uważali otrzymaną instrukcję za niezrozumiałą. Stwierdzono również, że osoby z niższym wykształceniem istotnie częściej niż pozostałe miały problemy ze zrozumieniem otrzymanej instrukcji. Większość respondentów (84\%) potwierdziła, że otrzymała wyjaśnienie od personelu medycznego $w$ zakresie przygotowania się do badania i oceniła pozytywnie jakość przekazu - 56\% uznało otrzymane informacje za zrozumiałe, a 36\% - za wystarczające. Ankietowani potwierdzili, że głównym źródłem wiedzy o przebiegu kolonoskopii był dla nich personel medyczny (67\%). Informacje samodzielnie uzyskało $22 \%$ badanych, a 11\% określiło, że nic nie wiedziało o przebiegu badania.

Dokładne przygotowanie jelita do kolonoskopii umożliwia pełną jego ocenę i ustalenie właściwego rozpoznania. Obecnie w trakcie przygotowania do kolonoskopii najczę- ściej stosowane są dwa środki: preparaty fosforanu sodu oraz glikol polietylenowy. Przeprowadzone liczne badania wykazują podobną skuteczność obu substancji i wskazują zarówno na zalety, jak też na wady obu środków przeczyszczających. Nadal brak jest optymalnego preparatu służącego do przygotowania do kolonoskopii [10].

W badaniach własnych wykazano, że etap przygotowania do kolonoskopii poprzez spożycie preparatu oczyszczającego jelita jest trudny dla większości pacjentów. Zdaniem $8 \%$ badanych smak podawanego preparat określiło jako dobry, a dla $19 \%$ był on obojętny. Negatywnie smak płynu odbierało $64 \%$ respondentów, a $48 \%$ uważało, że jest go za dużo. W trakcie przyjmowania preparatu respondenci swoje samopoczucie opisali głównie jako związane z nudnościami, bólem brzucha, głodem, osłabieniem. Zdaniem większości respondentów (66\%) występujące objawy utrudniały im wypicie preparatu. Opinię przeciwną wyraziło $26 \%$ badanych, a $8 \%$ nie spożyło zalecanej dawki płynu.

Kolonoskopia jest testem dla personelu w zachowaniu podstawowego prawa pacjenta jakim jest poszanowanie jego intymności. Dla przeprowadzenia badania pacjent musi się rozebrać w obecności personelu medycznego oraz traci kontrolę nad zwieraczami, co jeszcze bardziej podnosi poziom odczuwanego stresu i lęku przed zabiegiem $[12,13]$.

W badaniach własnych konieczność rozebrania się przed personelem medycznym wywoływała poczucie wstydu u 55\% respondentów. Problem ten nie dotyczył $33 \%$ ankietowanych. Stwierdzono, iż poczucie wstydu istotnie częściej towarzyszyło kobietom niż mężczyznom. Zdaniem większości respondentów (78\%) wstyd nie utrudniał im przygotowania się do badania.

Do determinantów warunkujących satysfakcję, jak i akceptację endoskopii, zalicza się: czas oczekiwania na badanie i czas jego trwania, rodzaj przygotowania, poziom lęku i bólu w trakcie badania oraz doświadczenie endoskopisty. Strach przed bólem w trakcie badania oraz brak pewności co do zasadności wykonania kolonoskopii stanowią główne powody, dla których pacjenci nie decydują się na wykonanie badania i rezygnują z możliwości udziału w badaniach przesiewowych [5]. Zgodnie z doniesieniami badań, dotyczących różnych grup społecznych, respondenci obawiają sięnie tylko samego bólu, ale także przygotowania do badania, poczucia wstydu oraz potencjalnych komplikacji [12].

Wbadaniachwłasnychstrach przedkolonoskopiąodczuwało $89 \%$ respondentów. Zestawieniedanych badawczych wykazało, że lęk u mężczyzn częściej wywoływała obawa o wynik, a u kobiet - możliwość wystąpienia powikłań. 
Zdaniem 31\% respondentów wiedza o możliwych powikłaniach utrudniała przygotowanie się im do badania. Opinię przeciwną wyraziło $44 \%$ badanych.

W wielu badaniach potwierdza się, że wygenerowanie dużego lęku było następstwem przekazania informacji po wykonanej procedurze, dotyczącej wykrycia patologii i pobrania materiału tkankowego do badania histopatologicznego, w celu potwierdzenia diagnozy. Lęk był manifestacją poczucia zagrożenia i obawy niekorzystnego rozpoznania [12].

Podsumowując, według $67 \%$ respondentów, przygotowanie do badania kolonoskopowego jest trudne. Proces przygotowania i przebieg badania generuje u pacjenta wysoki poziom stresu, którego źródłem jest przede wszystkim obawa o wynik badania oraz świadomość możliwych powikłań. Dodatkowo nagość i poczucie wstydu generują u chorych poddawanych kolonoskopii wysoki dyskomfort psychiczny. Kolonoskopia jest zatem wyzwaniem dla personelu medycznego, szczególnie pielęgniarek sprawujących bezpośrednią opiekę nad pacjentem. Przeprowadzona edukacja w zakresie przygotowania się do badania w opinii pacjentów musi być zrozumiała i wyczerpująca. W trakcie przygotowywania się przez pacjenta do badania niezbędne jest wsparcie psychiczne ze strony personelu medycznego, jak i osób bliskich towarzyszącym pacjentowi.

\section{Wnioski}

1. Przygotowanie do kolonoskopii jest trudne dla pacjentów i generuje specyficzne problemy.

2. Przeprowadzona edukacja w zakresie przygotowania do badania w opinii pacjentów była zrozumiała i wyczerpująca.

3. Kolonoskopia generuje wysoki poziom lęku u pacjenta, którego źródłem jest przede wszystkim obawa o wynik badania oraz świadomość możliwych powikłań.

4. Wysoki poziom lęku oraz nagość i poczucie wstydu mogą wpływać na niską zgłaszalność pacjentów do programu profilaktyki raka jelita grubego. Nagość i poczucie wstydu generują u chorych poddawanych kolonoskopii wysoki dyskomfort psychiczny.

5. Choroby wspótistniejące utrudniały przygotowanie się do badania pacjentom powyżej 65 roku życia.

6. Należy poszukiwać preparatu, który pozwoliłby w optymalny, przyjazny dla pacjenta sposób przygotować jelita do badania oraz zwiększyć udział badań z sedacją.

\section{Oświadczenia}

Oświadczenie dotyczące konfliktu interesów

Autorzy deklarują brak konfliktu interesów.

\section{Źródła finansowania}

Autorzy deklarują brak źródeł finansowania.

\section{Piśmiennictwo}

1. Cavanaugh MB. Badania laboratoryjne i obrazowe dla pielęgniarek, Wydawnictwo Lekarskie PZWL, Warszawa, 2006, s. $487-516$

2. Fibak J. Chirurgia Repetytorium, Wydawnictwo Lekarskie PZWL, Warszawa, 2007, s. 243-247.

3. Wronkowski Z, Brużewicz Sz. Nowotwory jelita grubego, Wydawnictwo Lekarskie PZWL, Warszawa, 2008, s. 41-52.

4. Deptała A, Wojtukiewicz MZ. (red.). Rak jelita grubego, Wydawnictwo Medyczne Termedia, Poznań, 2012, s. 17-72.

5. Bazaliński D, Kaczmarska D, Chmiel Z, Więch P, Dereń M. Determinanty warunkujące satysfakcję z profilaktycznej endoskopii jelita grubego, Nowa Medycyna, 2011, 3, s. 42-50.

6. Achord JL. Historia endoskopii przewodu pokarmowego, [W:] Ginsberg GG, Kochman ML, Norton I, Gostout ChJ. Kliniczna endoskopia przewodu pokarmowego, Medipage, Warszawa, 2009, s. 3-12.

7. Kubiak A, Kycler W, Trojanowski M. Epidemiologia i profilaktyka raka jelita grubego w Polsce, Problemy Higieny i Epidemiologii, 2014, 95(3), s. 636-642.

8. Krajowy Rejestr Nowotworów, http://onkologia.org.pl/nowotwory-zlosliwe-jelita-grubego-c18-21/\#r (data dostępu 02.05.2015)

9. Lightdale JR. Przygotowanie i sedacja pacjenta do endoskopii, [W:] Classen M, Tytgat GNJ, Lightdale ChJ. Endoskopia układu pokarmowego, Med.-Media, Warszawa, 2013, s. 59-66.

10. Wretowska D, Pracki M, Kamiński MF. Przygotowanie jelita grubego do kolonoskopii, Gastroenterologia Kliniczna, 2010 2, 1, s. 30-36.

11. Bambrowicz J, Cierzniakowska K, Szewczyk MT, Popow A Banaszkiewicz Z, Jawień A. Badania endoskopowe i opieka pielęgniarska nad chorym w pracowni endoskopii, Pielęgniarstwo Chirurgiczne i Angiologiczne, 2011, 1, s. 1-6.

12. Bazaliński D, Kaczmarska D, Bujalski D. Lęk i ból u osób poddanych profilaktycznej endoskopii jelita grubego, Współczesna Onkologia, 2010, 14, 5, s. 326-332.

13. Nesterowicz M. Prawo medyczne. Wydawnictwo Dom Organizatora, Toruń, 2007, s. 17-29.

14. Drozdowska U. Cywilnoprawna ochrona praw pacjenta. C. H. Beck, Warszawa, 2007, s. 141-152.

15. Jacek A, Ożóg K. Przestrzeganie praw pacjenta przez perso nel medyczny. Hygeia Public Health, 2012, 47, 3, s. 264-271.

Zaakceptowano do edycji: 20.08.19 Zaakceptowano do publikacji: 26.09.19

Adres do korespondencji:

Elżbieta Antos

Akademia Wychowania Fizycznego Józefa Piłsudskiego

w Warszawie

Wydziała Rehabilitacji

Zakład Pielęgniarstwa Klinicznego

ul. Marymoncka 34

00-968 Warszawa

tel. 608376007

e-mail: ela.antos@op.pl 